\title{
Growth, blood metabolites and hormones in calves fed diets with different amounts of energy and protein during the pre- or post-weaning periods
}

\author{
Fernández H. T. ${ }^{1}$, Busso C. A. ${ }^{1,2 \star}$, Laborde H. E. ${ }^{1,2}$, Torrea M. B. ${ }^{1}$, Fernández L. M. ${ }^{3}$, \\ López G. H. ${ }^{3}$, Delucchi F. ${ }^{3}$ and García B. N. ${ }^{3}$ \\ ${ }^{1}$ Departament of Agronomy, National University of the South (UNS), 8000 Bahía Blanca, Argentina. \\ ${ }^{2}$ CERZOS (CONICET), 8000 Bahía Blanca, Argentina. \\ ${ }^{3}$ Department of Biology, Biochemistry and Pharmacy, UNS, 8000, Bahía Blanca Argentina.
}

Accepted 4 March, 2012

\begin{abstract}
We investigated the effects of diets differing in energy and protein concentrations given during pre- and post-weaning on hormone and metabolite levels in association to parameters of growth. Sixteen Aberdeen Angus calves four-day-old were allocated in individual pens during 105 days in a randomized complete design. Animals consumed ad libitum various diets differing in proportion of energy and protein (A: $80 \%$ of concentrate, $20 \%$ alfalfa hay; B: $60 \%$ concentrate, $40 \%$ of alfalfa hay; C: $40 \%$ concentrate, $60 \%$ alfalfa hay, and D: $20 \%$ concentrate, $80 \%$ alfalfa hay). Also, calves consumed milk substitute up to 60-day-old day. Serum growth hormone and cortisol levels were not altered with diet changes $(P>0.05)$ neither during the pre- nor the post-weaning periods. Plasma insulin concentration average daily intake, glucose and thyroid hormone levels, and concentrations of ammonia nitrogen and propionic acid were greater $(P<0.01)$ for diets having higher than lower energy and protein levels during the post-weaning but not during the pre-weaning period. These results suggest inclusion of higher amounts of concentrate in the diet of weaned calves.
\end{abstract}

Key words: Calves, early weaning, energy, growth, hormones, metabolites, protein.

\section{INTRODUCTION}

Cow-calf operations are the most important activities in the temperate semi-arid rangeland region in Central Argentina known as the Caldenal $\left(35\right.$ to $40^{\circ} \mathrm{S}, 62$ to $66^{\circ}$ W) (Fernández and Busso, 1999; Fernández, 2003; Fernández et al., 2009). Current stocking rates ranged from 5 to 7 ha $\mathrm{cow}^{-1}$. The cattle production industry is one of the most important economic activities within this territory where natural grass species are commonly used as the only food source for animals (Fernández et al., 2009).

Early weaning is an increasing practice management in the Caldenal and the Monte (Giorgetti et al., 2006; Kugler et al., 2008) since it tends to improve reproductive

${ }^{*}$ Corresponding author. E-mail: cebusso@criba.edu.ar. Tel: 54291-4595126/4595102. Fax: 54-291-4595127. performance. This is because it generates more forage availability for reproductive functions by suppressing natural lactation. Average daily intake of calves receiving artificial nutrition was not detrimental when diets were adequate (Pordomingo, 2002). Calf nutrition during the lactating period has been considered critical for ruminant growth and maintenance of reasonable calf average daily weight gains (ADWG) after natality (Breier et al., 1986; Kugler et al., 2002).

Animal growth is regulated by a complex system of metabolic interactions, where nutrition plays an essential role. Kincaid (1980) indicated that an adequate proportion of hay and concentrate fosters rumen volume and papillae development, favoring growth in early weaned calves. Roughage intake of calves is greater when the roughage and concentrate are incorporated together into a single ration than when they are offered separately (Bartley, 1973). Lee et al. (2008) reported that the 
amount of protein and energy supplied with the milk replacer to Holstein calves during the pre-weaning period have various effects on feed consumption, body weight (BW), daily BW gain, health, and several blood metabolites (for example, serum glucose, creatinine and blood urea $\mathrm{N}$ ). The poor general appearance and lower BW of replacer-fed calves when compared to those milk fed prompted a demand for further research to improve the daily nutrient requirements and supply (Lee et al., 2008). Furthermore, protein levels may adversely affect liver and kidney functions in pre-weaned calves (Lohakare et al., 2006; Khan et al., 2007). Scientific literature regarding the effects of energy and protein contents during solid feed consumption, growth, blood metabolites and health parameters is limited in pre- and post-weaned Aberdeen Angus calves.

A close relationship exists between nutritional factors, hormones and metabolites versus animal growth. Nutritional changes affect plasma concentrations of insulin, growth hormone $(\mathrm{GH}), 3,5,3$ ' triiodotironine $\left(\mathrm{T}_{3}\right)$, thyroxine $\left(\mathrm{T}_{4}\right)$ and metabolites such as glucose, ammonia nitrogen $\left(\mathrm{N}-\mathrm{NH}_{3}\right)$ and volatile fatty acid (VFA) (Gerrits et al., 1998; Todini et al., 2007a, b; Acuti et al., 2009). Changes in nutrition are closely associated to growth. Despite the importance of this information, no studies have yet addressed the effects of different diet types on hormone and metabolite levels, and their association with early-weaned calf growth.

This study was conducted to evaluate the effects of nutrition on hormone and metabolite levels, and their association with growth parameters after feeding various levels of energy and protein during the pre- and postweaning periods in Aberdeen Angus calves. The hypothesis is that increasing the energy and protein levels during the post-weaning, but not the pre-weaning, period increases feed consumption, average daily intake, BW gain, hormones and glucose in blood, ammonia nitrogen and VFA in the rumen of Aberdeen Angus calves.

\section{MATERIALS AND METHODS}

\section{Animals, diets, experimental design and procedure}

This study was conducted in the experimental field of the Departamento de Agronomía, Universidad Nacional del Sur (3847'S, 6237'W), Argentina. Sixteen Aberdeen Angu s male calves (mean $\pm 1 \mathrm{SE}=35.88 \pm 1.40 \mathrm{~kg}$ ) were weaned at four-dayold and identified with ear tags. Immunity was verified following the Glutaraldehyde test (Berra et al., 1991). Each animal was randomly assigned to individual pens $(1.60 \times 1.80 \mathrm{~m})$. These pens were distributed at random in a closed barn $(10 \times 10 \mathrm{~m})$, had nonskid floor and a straw bed. Mean air temperature inside the barn was 21 $\pm 5.5^{\circ} \mathrm{C}$.

High incidence of diarrhea is usually related with the sanitary management housing conditions and immune status of the calves (Khan et al., 2007). A few, slight diarrhea episodes occurred only at the beginning of the study, when calves were separated from their mothers and were fed with artificial milk. These episodes, limited to two animals at the initiation of the study, were solved providing moisturizing salts during two/three days. No diarrhea occurred on any animal when they were fed with the different study diets. Calves received a triple vaccine (symptomatic carbuncle, gaseous gangrene and enterotoxaemia) at 60-day-old, and a triple viral vaccine + pasteurella (infectious bovine rhinotracheitis, bovine viral diarrhea, parainfluenza and pasteurellosis) and an antiparasitism at 80-day-old. Twice daily, animal health and faeces consistency were monitored using a four-point scale from 1 (normal) to 4 (liquid) following the study of Larson et al. (1977). Calves exhibiting two consecutive fecal scores $\geq 3$ received an antibiotic (Terramicina L.A, Pfizer, Guarulhos, Sao Paulo, and Brasil) and one antidiarrheic (Diafin, Konig or Curso Stop, Agroisumos, Buenos Aires, Argentina). Also, milk was replaced by an electrolyte solution (Cooperación, Asociación de Cooperativas Argentinas, Buenos Aires, Argentina) that was fed twice daily until the fecal score was reduced to 1 .

Diets having a high proportion of concentrate (80 and 60\%), averaging $19.51 \% \mathrm{CP}$, were provided to the study animals to reach adequate ADG, as recommended by Akayesu et al. (1994). Crude protein averaged $18.14 \%$ on animals receiving a low proportion of concentrate (40 and 20\%). Diets were formulated with two ingredients: dry alfalfa hay $(\mathrm{H})$ and a commercial concentrate $(C$; $40 \%$ corn grain, $20 \%$ soybean meal, $10 \%$ sunflower pellets, $25 \%$ wheat bran and $5 \%$ mineral-vitamin mixture). Dry alfalfa hay was ground using a $10 \mathrm{~mm}$-mesh in a mill hammer. Treatments were: A) 80 concentrate, $20 \%$ hay; B) $60 \%$ concentrate, $40 \%$ hay; C) $40 \%$ concentrate, $60 \%$ hay, and D) $20 \%$ concentrate and $80 \%$ hay. Four animals (replicates) were used per treatment using a completely randomized design. The study lasted 105 days. It included a 56-day pre-weaning period with a milk substitute (MS) supply followed by a 49-day post-weaning period. Weaning was conducted when animals were 60-day-old. During the post-weaning period, the MS was suppressed from the diet. The MS was diluted to $120 \mathrm{~g} \mathrm{~L}^{-1}$ in water at a temperature of $38 / 400^{\circ} \mathrm{C}$. Four liters of thi s solution were supplied twice daily at 8:00 A.M. and 6 P.M. during the pre-weaning period. One week before weaning, the MS was reduced $15 \%$ daily in all treatments. During the study period, diets were consumed ad libitum, allowing $10 \%$ refusal. Daily consumption was recorded subtracting the amount refused from that offered. Chemical composition of provided food and diets are indicated in Table 1. Dry matter (DM), crude protein (CP), neutral detergent fiber (NDF) and acid detergent fiber (ADF) were analyzed on $\mathrm{C}, \mathrm{MS}$, and $\mathrm{H}$ diets following AOAC (1990). Metabolizable energy (ME) of $\mathrm{C}$ and $\mathrm{H}$ was estimated after Menke and Steingass (1988). Milk substitute and ME was reported by the manufacturer.

\section{Blood sampling}

From day four to the end of the study, blood samples were obtained weekly at 7:00 AM by puncturing of the caudal vein. Samples were taken at the same hour each week, and in the same order (Mears and Schaaljie, 1993). Blood samples were centrifuged $(2,300 \mathrm{~g} \times$ $15 \mathrm{~min}$ at $4^{\circ} \mathrm{C}$ ), and serum was removed and stored at $-70^{\circ} \mathrm{C}$ until assayed.

\section{Collection of rumen fluid}

Rumen fluid was extracted using flexible plastic tubing. It had a stainless steel extremely joined to a vacuum pump. Fluid was filtered through eight gauze layers. $10 \mathrm{ml}$ of filtrate were mixed with $10 \mathrm{ml}$ of hydrochloride acid $0.2 \mathrm{~N}$, and centrifuged $(15,000 \mathrm{~g} \times 30$ $\min$ at $\left.4^{\circ} \mathrm{C}\right)$. Floating material was frozen at $-20^{\circ} \mathrm{C}$ fo $r$ future analysis. Fifteen days after weaning, rumen fluid was extracted to determine the minimum $\mathrm{pH}$ in the diets. This was done before the morning feeding and 2, 4, 6 and $8 \mathrm{~h}$ after feeding. Minimum $\mathrm{pH}$ 
Table 1. Chemical composition of the study food and diets.

\begin{tabular}{lccccccc}
\hline \multirow{2}{*}{ Item } & \multicolumn{3}{c}{ Foods } & \multicolumn{3}{c}{ Diets } \\
\cline { 2 - 8 } & Milk substitute (MS) & Concentrate & Hay (H) & A & B & C & D \\
\hline DM (\%) & 96.11 & 92.10 & 90.43 & 92.94 & 92.94 & 93.18 & 92.67 \\
CP (\%) & 21.70 & 19.80 & 16.00 & 19.81 & 19.21 & 18.54 & 17.74 \\
NDF (\%) & - & 24.60 & 53.46 & 38.12 & 39.94 & 42.11 & 46.55 \\
ME (MJ/kg) & 14.65 & 13.82 & 9.00 & 12.44 & 11.72 & 11.10 & 10.51 \\
ASH (\%) & - & - & & 7.84 & 7.92 & 8.56 & 9.57 \\
ADF (\%) & - & - & & 15.07 & 20.07 & 24.59 & 28.92 \\
\hline
\end{tabular}

$\mathrm{DM}=$ dry matter, $\mathrm{CP}=$ crude protein, $\mathrm{NDF}=$ neutral detergent fiber, $\mathrm{ME}=$ metabolizable energy, $\mathrm{ASH}=\mathrm{ash}, \mathrm{ADF}=$ acid detergent fiber. $\mathrm{Diets}: \mathrm{A}=$ milk substitute $(\mathrm{MS})+80 \%$ concentrate $(\mathrm{C}) / 20 \%$ hay $(\mathrm{H})$ and $80 \% \mathrm{C} / 20 \% \mathrm{H}$ in post-weaning; $\mathrm{B}=\mathrm{MS}+60 \% \mathrm{C} / 40 \% \mathrm{H}$ and $60 \% \mathrm{C} / 40 \% \mathrm{H}$ in postweaning; $\mathrm{C}=\mathrm{MS}+40 \% \mathrm{C} / 60 \% \mathrm{H}$ and $40 \% \mathrm{C} / 60 \% \mathrm{H}$ in post-weaning; $\mathrm{D}=\mathrm{MS}+20 \% \mathrm{C} / 80 \% \mathrm{H}$ and $20 \% \mathrm{C} / 80 \% \mathrm{H}$ in post-weaning.

values were reached $2 \mathrm{~h}$ after feeding in diets $A$ and $B$, and 4 and 6 $\mathrm{h}$ after feeding in diets $\mathrm{C}$ and $\mathrm{D}$, respectively. These times were used for future samplings of rumen fluid. Five days later, four rumen fluid samples were obtained at weekly intervals at fasting and predetermined times for $\mathrm{N}-\mathrm{NH}_{3}$ determinations on each study diet. The first and last rumen fluid samples were used for VFA analysis.

\section{Body weight and voluntary intake}

Food intake was recorded daily, and body weight was measured weekly at the same time on each weighing date. No animal death was registered on any treatment during the experiment.

\section{Analytical methods}

Glucose concentrations were measured by a glucose-oxidase procedure (Sera-Pak, AMES, USA) in blood serum. Insulin, cortisol, $\mathrm{T}_{3}, \mathrm{~T}_{4} \mathrm{GH}$ concentrations were determined by radioimmunoassay using commercial kits (Coat-A-Count, Diagnostic Products Corporation, Los Angeles, CA, USA; Williams et al., 1987). The sensitivity of the insulin assay was $1.0 \mathrm{mU} \mathrm{L}^{-1}$; the intra- and interassay coefficients of variation were 8.25 and $8.81 \%$, respectively. Intra- and inter-assay CVs for cortisol were 7 and $7.9 \%$, respectively, additionally; sensitivity for cortisol was $0.15 \mu \mathrm{g} \mathrm{dL}^{-1}$. $\mathrm{T}_{3}$ and $\mathrm{T}_{4}$ were total (including protein-bound) concentrations. Assay sensitivity was $7 \mathrm{ng} \mathrm{dL}^{-1}$ for $\mathrm{T}_{3}$ and $0.25 \mathrm{ug} \mathrm{dL}^{-1}$ for $\mathrm{T}_{4}$. The intraand inter-assay coefficients of variation were 8.9 and $10.0 \%$ for $\mathrm{T}_{3}$, and 3.8 and $14.5 \%$ for $\mathrm{T}_{4}$, respectively. Rumen fluid $\mathrm{N}-\mathrm{NH}_{3}$ concentrations $\left(\mathrm{mg} \mathrm{mL}^{-1}\right)$ were analyzed by the phenol-hypochlorite colorimetric reaction (Weatherburn, 1967), using an ammonium sulfate solution as standard. Volatile fatty acid concentrations were determined by gas chromatography (Shimadzu, GC-14 A, Japan; Friggens et al., 1998) of clarified rumen fluid by Nukol capillary column (30 m $\times 0.25 \mathrm{~mm} \times 0.25 \mu \mathrm{m}$, Supelco, Belleforte, PA, USA).

\section{Statistical analysis}

Average daily weight gains, hormones and metabolites were analyzed employing a two-way analysis of variance with repeated measures (Biomedical Computer Programs; Dixon, 1992). Each animal constituted an experimental unit. Calf body weight, organic matter $(\mathrm{OM})$, nitrogen $(\mathrm{N})$ and metabolizable energy data were analyzed using analysis of variance (Steel and Torrie, 1980). When $F$ tests were significant $(P<0.05)$, mean differences were assessed by Turkey's test (Steel and Torrie, 1980).

\section{RESULTS}

\section{Pre-weaning period}

Consumption of solid food started when calves were 20days-old. At weaning, average daily intakes were: $1.28 \pm$ $0.1 ; 1.64 \pm 0.1 ; 1.60 \pm 0.1$ and $1.14 \pm 0.03 \mathrm{~kg}$ for diets $A$, $B, C$ and $D$ respectively. There were no differences at $(P$ $>0.05$ ) among treatments (diets) for ADWG, OM, N, ME intake, NDF and food conversion efficiency (Table 2). Also, concentrations of cortisol, $\mathrm{GH}$, insulin, $\mathrm{T}_{3}, \mathrm{~T}_{4}$ (Table 2) and glucose (Table 2) were not significantly different at $(P>0.05)$ among treatments during this period.

\section{Post-weaning period}

Calves fed diets having a high concentrate proportion (diets $A$ and $B$ ) showed greater $(P<0.01) A D W G$ than those fed with higher hay fraction (diets $C$ and $D$; Table $3)$. Diets $A$ and $B$ presented higher $(P<0.01) O M, N$, and ME intake than diet $D$ (Table 3 ). Food conversion efficiency at $(P<0.05)$ was higher in $\operatorname{diet} C$ than $A$ (Table 3). Concentrations of $\mathrm{GH}$ and cortisol did not differ at $(\mathrm{P}>$ 0.05 ) among diets (Table 3). Nevertheless, diet with higher concentrate proportion resulted in greater $(\mathrm{P}<$ 0.01 ) concentrations of insulin (diets $A$ and $B$ ) and $T_{3}$ (diet A) than those with lower proportion of concentrate (diets $\mathrm{C}$ and D) (Table 3). Concentrations of $\mathrm{T}_{4}$ were higher at $(P<0.01)$ in diets $A, B$ and $C$ (Table 3$)$ than in diet $D$. Glucose concentrations were higher $(P<0.01)$ in diet $A$ than in diets $C$ and $D$; and in diet $B$ than $D$ (Table 3 ). Mean concentrations of $\mathrm{N}-\mathrm{NH}_{3}$ at fasting did not differ significantly $(P>0.05)$ among diets (Table 3$)$. After feeding, however, concentrations of $\mathrm{N}-\mathrm{NH}_{3}$ were higher $(\mathrm{P}<0.05)$ in diet $\mathrm{B}$ than $\mathrm{D}$. This greater $(\mathrm{P}<0.05) \mathrm{N}-\mathrm{NH}_{3}$ concentration in diet $\mathrm{B}$ than $\mathrm{D}$ (Table 3 ) was determined by a greater $(p<0.01) \mathrm{N}$ consumption when animals were fed with the first than with the second diet (Table 3). No differences $(P>0.05)$ were found among diets for concentrations of acetic and butyric acids both 20-day- 
Table 2. Pre-weaning parameters measured on Aberdeen Angus calves: Initial animal weight (4-day-old), animal weight at 60-dayold, average daily gain (ADWG), food conversion efficiency, consumption variables and hormone concentrations.

\begin{tabular}{lcccc}
\hline \multirow{2}{*}{ Variable } & \multicolumn{3}{c}{ Diets } \\
\cline { 2 - 5 } & A & B & C & D \\
\hline Initial weight (Kg; 4-day-old) & $32.00 \pm 1.00^{\mathrm{a}}$ & $34.50 \pm 1.44^{\mathrm{a}}$ & $41.25 \pm 3.82^{\mathrm{a}}$ & $35.75 \pm 2.50^{\mathrm{a}}$ \\
Weight at 60-day-old (kg) & $51.88 \pm 2.16^{\mathrm{a}}$ & $57.63 \pm 4.20^{\mathrm{a}}$ & $63.00 \pm 6.48^{\mathrm{a}}$ & $52.00 \pm 4.26^{\mathrm{a}}$ \\
ADWG (Kg d ${ }^{-1}$ ) & $0.35 \pm 0.05^{\mathrm{a}}$ & $0.41 \pm 0.05^{\mathrm{a}}$ & $0.39 \pm 0.05^{\mathrm{a}}$ & $0.29 \pm 0.05^{\mathrm{a}}$ \\
Feed conversion (OM/ADWG) & $2.14 \pm 0.18^{\mathrm{a}}$ & $2.23 \pm 0.20^{\mathrm{a}}$ & $2.16 \pm 0.10^{\mathrm{a}}$ & $2.74 \pm 0.46^{\mathrm{a}}$
\end{tabular}

\section{Consumption}

$\begin{array}{lcc}\text { OM }\left(\mathrm{g} \mathrm{d}^{-1}\right) & 727.96 \pm 46.08^{\mathrm{a}} & 894.98 \pm 63.24^{\mathrm{a}} \\ \mathrm{N}\left(\mathrm{g} \mathrm{d}^{-1}\right) & 26.30 \pm 1.59^{\mathrm{a}} & 31.52 \pm 2.11^{\mathrm{a}} \\ \mathrm{ME}(\mathrm{MJ} / \mathrm{d}) & 10.76 \pm 0.62^{\mathrm{a}} & 12.64 \pm 0.80^{\mathrm{a}} \\ \mathrm{NDF}\left(\mathrm{g} \mathrm{d}^{-1}\right) & 134.95 \pm 19.06^{\mathrm{a}} & 213.88 \pm 27.45^{\mathrm{a}}\end{array}$

\begin{tabular}{|c|c|}
\hline $823.32 \pm 79.69^{a}$ & $730.40 \pm 42.45^{a}$ \\
\hline $28.86 \pm 2.44^{\mathrm{a}}$ & $25.53 \pm 1.36^{a}$ \\
\hline $11.51 \pm 0.89^{a}$ & $10.26 \pm 0.51^{\mathrm{a}}$ \\
\hline $186.28 \pm 40.67^{a}$ & $158.43 \pm 23.29^{a}$ \\
\hline
\end{tabular}

\section{Hormones}

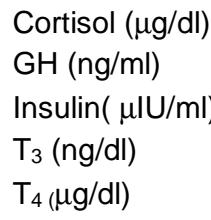

$$
\begin{gathered}
0.28 \pm 0.02^{\mathrm{a}} \\
1.38 \pm 0.05^{\mathrm{a}} \\
2.68 \pm 0.16^{\mathrm{a}} \\
99.43 \pm 5.01^{\mathrm{a}} \\
4.15 \pm 0.33^{\mathrm{a}}
\end{gathered}
$$

$$
\begin{gathered}
0.33 \pm 0.02^{\mathrm{a}} \\
1.30 \pm 0.02^{\mathrm{a}} \\
2.94 \pm 0.13^{\mathrm{a}} \\
89.99 \pm 5.71^{\mathrm{a}} \\
4.02 \pm 0.30^{\mathrm{a}}
\end{gathered}
$$

\section{Other compounds}

Glucose $\left(\mathrm{g} \mathrm{I}^{-1}\right)$

$0.82 \pm 0.03^{\mathrm{a}}$

$0.80 \pm 0.02^{\mathrm{a}}$

$0.71 \pm 0.02^{\mathrm{a}}$

$0.70 \pm 0.06^{\mathrm{a}}$

Hormones and glucose are blood concentrations. Animals were fed with diets: A = milk substitute $(\mathrm{MS})+80 \%$ concentrate $(\mathrm{C}) / 20 \%$ hay $(\mathrm{H}) ; \mathrm{B}=\mathrm{MS}+60 \% \mathrm{C} / 40 \% \mathrm{H} ; \mathrm{C}=\mathrm{MS}+40 \% \mathrm{C} / 60 \% \mathrm{H} ; \mathrm{D}=\mathrm{MS}+20 \% \mathrm{C} / 80 \% \mathrm{H}$. ADWG= average daily weight gain, OM= organic matter, $\mathrm{N}=$ nitrogen, $\mathrm{ME}=$ metabolizable energy, $\mathrm{NDF}=$ neutral detergent fiber, $\mathrm{GH}=$ growth hormone, $\mathrm{T} 3=$ triiodotironine, $\mathrm{T} 4=$ thyroxine . Each value is the mean \pm 1 SE of $n=4$. Values with equal letters within rows do not differ significantly at $P \leq 0.05$ (Turkey's test).

after weaning and at the end of the study at post-weaning (Table 4). Propionic acid concentrations at the end of the study in this treatment, however, were greater $(P<0.05)$ in diet $B$ than in diet $D$ (Table 4).

\section{DISCUSSION}

The higher ADWG observed in diets $A$ and $B$ than in diets $C$ and $D$ during the post-weaning period could be attributed to an earlier development of the rumen before weaning. This was associated with a highest ratio of concentrate/hay in the diet. Mc Donald et al. (1995) indicated that rumen development was stimulated by the presence of concentrates and hay in the pre-weaning diet. Murdock and Wallenius (1980) suggested that early weaning was favored by high proportions of grain in the diet that favored rumen development. The high energy and protein levels in the concentrate determined a greater $\mathrm{OM}, \mathrm{N}, \mathrm{ME}$ intake with diets $\mathrm{A}$ and $\mathrm{B}$ than $\mathrm{D}$ during post-weaning.

Although, diets varied in protein and energy concentrations, no differences were found in $\mathrm{GH}$ and cortisol levels during the pre- and post-weaning periods.
Other authors (Mears and Kozub, 1994) also reported a lack of dietary effects on basal GH concentrations for diets differing in DM digestibility and protein content. In contrast, Cole et al. (1988) found that GH concentrations in sheep were higher in low than high energy level diets. It is suggested that a shorter time among sampling periods in our study might have added further information on the relationship between animal food quality and $\mathrm{GH}$ levels. This is because the diurnal release of $\mathrm{GH}$ is episodic (Trenkle, 1989).

High cortisol concentrations are an indication of animal stress (Wohlt et al., 1994). These authors observed high cortisol values immediately after weaning, which thereafter declined to normal concentrations. These results are similar to those in our study, where no differences were found in cortisol concentrations during both the pre-and post-weaning periods. This suggests that management procedures kept calf stress to a minimum in this study, which is critical in experiments of hormonal dosage and this is because stress may alter hormonal concentrations (Gifford et al., 2004). Glucocorticoids are catabolic hormones that might inhibit animal growth at high concentrations (Quaia et al., 2000).

In agreement with results of Chilliard et al. (1998), the 
Table 3. Post-weaning parameters measured on Aberdeen Angus calves: Initial animal weight; weight at 60-day-old; average daily weight gain (ADWG), food conversion efficiency, consumption variables and hormone concentrations.

\begin{tabular}{|c|c|c|c|c|}
\hline \multirow{2}{*}{ Variable } & \multicolumn{4}{|c|}{ Diets } \\
\hline & $\mathbf{A}$ & B & $\mathbf{C}$ & D \\
\hline Initial weight (kg) & $51.88 \pm 2.16^{a}$ & $57.63 \pm 4.20^{\mathrm{a}}$ & $63.00 \pm 6.48^{a}$ & $52.00 \pm 4.26^{a}$ \\
\hline Weight at 60-day-old (kg) & $94.00 \pm 5.92^{\mathrm{a}}$ & $99.75 \pm 5.23^{\mathrm{a}}$ & $92.50 \pm 8.57^{\mathrm{a}}$ & $75.50 \pm 5.52^{\mathrm{a}}$ \\
\hline ADWG $\left(\mathrm{kg} \mathrm{d}^{-1}\right)$ & $0.86 \pm 0.08^{\mathrm{a}}$ & $0.86 \pm 0.03^{\mathrm{a}}$ & $0.60 \pm 0.05^{\mathrm{b}}$ & $0.48 \pm 0.03^{b}$ \\
\hline Food conversion efficiency (OM/ADWG) & $2.14 \pm 0.04^{\mathrm{a}}$ & $2.38 \pm 0.12^{\mathrm{ab}}$ & $2.92 \pm 0.28^{b}$ & $2.55 \pm 0.19^{\mathrm{ab}}$ \\
\hline \multicolumn{5}{|l|}{ Consumption } \\
\hline $\mathrm{OM}\left(\mathrm{g} \mathrm{d}^{-1}\right)$ & $1841.13^{* *} \pm 163.24^{a}$ & $2045.08^{* *} \pm 116.86^{\mathrm{a}}$ & $1752.92 \pm 160.50^{\mathrm{ab}}$ & $1225.63 \pm 76.95^{b}$ \\
\hline$N\left(g^{-1}\right)$ & $63.33^{* *} \pm 5.61^{a}$ & $68.18^{* *} \pm 3.90^{\mathrm{a}}$ & $56.94 \pm 5.21^{\mathrm{ab}}$ & $38.49 \pm 2.42^{b}$ \\
\hline $\mathrm{ME}(\mathrm{MJ} / \mathrm{d})$ & $24.8^{* t} \pm 2.20^{\mathrm{a}}$ & $26.04^{* *} \pm 1.49^{\mathrm{a}}$ & $21.19 \pm 1.94^{\mathrm{ab}}$ & $14.11 \pm 0.89^{b}$ \\
\hline $\operatorname{NDF}\left(\mathrm{g} \mathrm{d}^{-1}\right)$ & $761.54 \pm 67.52^{\mathrm{a}}$ & $887.06 \pm 50.69^{\mathrm{a}}$ & $807.25 \pm 73.91^{\mathrm{a}}$ & $630.91 \pm 39.61^{a}$ \\
\hline \multicolumn{5}{|l|}{ Hormones } \\
\hline Cortisol ( $\mu \mathrm{g} / \mathrm{dl})$ & $0.36 \pm 0.02^{\mathrm{a}}$ & $0.47 \pm 0.06^{\mathrm{a}}$ & $0.46 \pm 0.03^{\mathrm{a}}$ & $0.51 \pm 0.04^{\mathrm{a}}$ \\
\hline $\mathrm{GH}(\mathrm{ng} / \mathrm{ml})$ & $1.24 \pm 0.05^{\mathrm{a}}$ & $1.24 \pm 0.07^{\mathrm{a}}$ & $1.40 \pm 0.10^{\mathrm{a}}$ & $1.33 \pm 0.02^{\mathrm{a}}$ \\
\hline Insulin $(\mu \mathrm{IU} / \mathrm{ml})$ & $6.42^{* *} \pm 0.87^{\mathrm{a}}$ & $5.29^{* *} \pm 0.60^{\mathrm{a}}$ & $3.56 \pm 0.48^{b}$ & $3.02 \pm 0.18^{b}$ \\
\hline $\mathrm{T}_{3}(\mathrm{ng} / \mathrm{dl})$ & $129.67^{* *} \pm 13.20^{\mathrm{a}}$ & $122.17 \pm 13.36^{\mathrm{ab}}$ & $108.78 \pm 10.93^{b}$ & $78.41 \pm 6.99^{c}$ \\
\hline $\mathrm{T}_{4}(\mu \mathrm{g} / \mathrm{dl})$ & $5.60^{* *} \pm 0.40^{\mathrm{a}}$ & $5.54^{* *} \pm 0.48^{\mathrm{a}}$ & $4.63^{* \star} \pm 0.61^{\mathrm{a}}$ & $3.33 \pm 0.46^{b}$ \\
\hline \multicolumn{5}{|l|}{ Other compounds } \\
\hline Glucose $\left(\mathrm{g} \mathrm{l}^{-1}\right)$ & $0.92 \pm 0.05^{\mathrm{a}}$ & $0.89 \pm 0.03^{\mathrm{ab}}$ & $0.77 \pm 0.02^{b c}$ & $0.65 \pm 0.03^{c}$ \\
\hline $\mathrm{N}-\mathrm{NH}_{3}$ fasting $(\mathrm{mg})$ & $3.99 \pm 0.71^{\mathrm{a}}$ & $4.32 \pm 1.04^{\mathrm{a}}$ & $4.42 \pm 0.90^{\mathrm{a}}$ & $4.17 \pm 0.79^{\mathrm{a}}$ \\
\hline $\mathrm{N}-\mathrm{NH}_{3}$ post-ingesta ${ }^{1}(\mathrm{mg})$ & $5.51 \pm 0.28^{\mathrm{ab}}$ & $5.96 \pm 0.33^{\mathrm{a}}$ & $5.12 \pm 0.13^{\mathrm{ab}}$ & $3.80 \pm 0.14^{b}$ \\
\hline
\end{tabular}

Hormones and glucose are blood concentrations. Animals were fed with the diets: $\mathrm{A}=80 \% \mathrm{C} / 20 \% \mathrm{H} ; \mathrm{B}=60 \% \mathrm{C} / 40 \% \mathrm{H} ; \mathrm{C}=$ $40 \% \mathrm{C} / 60 \% \mathrm{H} ; \mathrm{D}=20 \% \mathrm{C} / 80 \% \mathrm{H} . \mathrm{ADWG}=$ average daily weight gain, $\mathrm{OM}=$ organic matter, $\mathrm{N}=$ nitrogen, $\mathrm{ME}=$ metabolizable energy, $\mathrm{NDF}=$ neutral detergent fiber, $\mathrm{GH}=$ growth hormone, $\mathrm{T} 3=$ triiodotironine, $\mathrm{T} 4=$ thyroxine, $\mathrm{N}-\mathrm{NH}_{3}=$ ammonia nitrogen are in rumen fluid. Diets $A$ and $B=2 h$-; diet $C=4 h$ - and diet $D=6$ h-post-ingesta. Each value is the mean \pm 1 SE of $n=4$. Values with equal letters within rows do not differ significantly at $P \leq 0.05$ (Turkey's test).

Table 4. Acetic, propionic and butyric acid after feeding ${ }^{1}$.

\begin{tabular}{lcccc}
\hline 20 Days after weaning & \multicolumn{4}{c}{ Diets } \\
\cline { 2 - 5 } (mol/100 mol) & A & B & C & D \\
\hline Acetic acid & $56.27 \pm 1.56^{\mathrm{a}}$ & $53.79 \pm 1.02^{\mathrm{a}}$ & $55.73 \pm 2.17^{\mathrm{a}}$ & $58.46 \pm 1.25^{\mathrm{a}}$ \\
Propionic acid & $29.82 \pm 1.62^{\mathrm{a}}$ & $30.19 \pm 1.74^{\mathrm{a}}$ & $25.94 \pm 2.02^{\mathrm{a}}$ & $25.04 \pm 0.49^{\mathrm{a}}$ \\
Butyric acid & $9.89 \pm 0.21^{\mathrm{a}}$ & $11.54 \pm 0.76^{\mathrm{a}}$ & $11.63 \pm 1.53^{\mathrm{a}}$ & $12.88 \pm 0.70^{\mathrm{a}}$ \\
& & & & \\
End of study & & & & $51.93 \pm 2.48^{\mathrm{a}}$ \\
Acetic acid & & & $49.60 \pm 1.30^{\mathrm{a}}$ & $25.77 \pm 1.00^{\mathrm{b}}$ \\
Propionic acid & $51.25 \pm 1.73^{\mathrm{a}}$ & $48.86 \pm 1.84^{\mathrm{a}}$ & $27.66 \pm 0.77^{\mathrm{ab}}$ & $16.23 \pm 2.34^{\mathrm{a}}$ \\
Butyric acid & $31.62 \pm 2.13^{\mathrm{ab}}$ & $33.69 \pm 1.64^{\mathrm{a}}$ & $16.87 \pm 1.40^{\mathrm{a}}$ & $12.59 \pm 0.87^{\mathrm{a}}$ \\
\hline
\end{tabular}

Diets: $\mathrm{A}=80 \% \mathrm{C} / 20 \% \mathrm{H} ; \mathrm{B}=60 \% \mathrm{C} / 40 \% \mathrm{H} ; \mathrm{C}=40 \% \mathrm{C} / 60 \% \mathrm{H} ; \mathrm{D}=20 \% \mathrm{C} / 80 \% \mathrm{H}$. ${ }^{1} \mathrm{~T}$ wo, four or six hours after feeding diets $\mathrm{A}$ and $\mathrm{B}$, $C$ or $D$, respectively. Each value is the mean \pm 1 SE of $n=4$. Values with different letters within rows differ significantly at $P<0.05$ (Turkey's test).

higher insulin concentrations were recorded when feeding high than low concentrate diets during postweaning. An increase in VFA is anticipated in response to a high concentrate ratio (Mc Donald et al., 1995). Several authors reported that propionic acid stimulates insulin secretion in pre-ruminants and ruminants (Chilliard et al., 
1998; Matsunaga et al., 1999). It appears that this response is linked to the activation of muscarinic receptors through the parasympathetic system (Sano et al., 1993).

Measurement of $T_{3}$ and $T_{4}$ thyroid hormones is scarce in young calves. In addition, the relationship between food intake and basal $T_{3}$ concentrations is not yet clear. Ekpe and Christopherson (2000) observed a decrease in $\mathrm{T}_{3}$ concentrations as a result of dietary constraints in sheep. The hormone concentrations were restored after re-feeding. On the other hand, Ellenberger et al. (1989) did not find a response between $T_{3}$ concentration and either dietary restrictions or after re-feeding. In fact, little information is available of nutrition effects on thyroid hormone concentrations in pre-ruminant calves (Gerrits et al., 1998; Blome et al., 2003). We were unable to find differences in $T_{3}$ concentrations between diets during the pre-weaning period. However, concentrations of this hormone were higher on animals fed with high than low concentrate diets during post-weaning. Similar results were reported by Gerrits et al. (1998) in Holstein calves and Zhang et al. (2005) in sheep. Danforth and Burger (1989) suggested that increases in energy consumption led to higher plasma binding-protein concentrations which are associated to increased $\mathrm{T}_{3}$ levels.

Concentrations of $\mathrm{T}_{4}$ appeared to be consistent with changes in energy and protein metabolism (Bartlett et al., 2006). Hammond et al. (1984) observed that $T_{4}$ levels increased when protein ingestion also increased. This is in agreement with our results: $\mathrm{T}_{4}$ levels were higher on high than low diet concentrate content after weaning. However, the lack of significant differences between diets $A, B$ and $C$, would suggest that $T_{4}$ is less sensitive to diet changes than $\mathrm{T}_{3}$. The major form of thyroid hormone secretion is $T_{4}$, which is deiodinated in liver and kidney to $\mathrm{T}_{3}$. On the other hand, $\mathrm{T}_{3}$ is more metabolically active, has a shorter half life and is a potent inhibitor of the thyrotropin hormone.

Pre- and post-weaning glucose concentrations are in agreement with findings of Swenson (1981). Several authors have reported higher glucose concentrations when sheep and calves were fed with greater than lower energy and protein rations (Santra and Pathak, 2000). This is in agreement with our results during the postweaning period. Rich energy and protein diets enhance the production of propionic acid, a major precursor of glucose.

The measurement of $\mathrm{N}-\mathrm{NH}_{3}$ in rumen fluid of calves fed with different diets at weaning has been barely studied. Several works used urea as a protein supplement (Elías, 1986) or examined the changes of blood nitrogen levels with age in early-weaned calves (Lee et al., 2008). Higher concentrations of $\mathrm{N}-\mathrm{NH}_{3}$ in diet $\mathrm{B}$ than $\mathrm{D}$ could be attributed to a higher protein ingestion in the first than in the second diet. These results disagree with findings of Zitnan et al. (1998), who determined higher concentrations of $\mathrm{NH}_{3}$ in animals fed with hay than in those only supplied with concentrate. However, $\mathrm{N}-\mathrm{NH}_{3}$ availability in the rumen depends not only on diet $\mathrm{CP}$ concentration and degradability but also on total nutrient digestibility. $\mathrm{N}$ $\mathrm{NH}_{3}$ concentrations in our study are in line with the results used to obtain an optimum bacterial growth (3.3 to $8.5 \mathrm{mg} / 100 \mathrm{ml}$; Schaefer et al., 1980).

In dairy steers, the source of digested carbohydrates did not affect the total concentration of VFA in the rumen (Bragg et al., 1986). However, as calves increase their solid food intake, VFA increasingly become important energy sources. No differences were found for acetic and butyric acids among diets, although, propionic acid concentrations were higher in diet B than D at the end of the study. This may be associated with greater energy consumption in high than low concentrate diets, results similar to those of Kincaid (1980). Mc Donald et al. (1995) reported that concentrate and hay-rich diets during preweaning stimulate rumen development, favoring growth of rumen mucosa area and VFA absorption (Liebich et al., 1987).

Our results showed that high energy diets yield more propionic acid, which can readily be converted to glucose through gluconeogenesis in the liver (Bellver et al., 1995). This organ is majorly responsible for the increase of glucose availability in ruminants. Other precursors in the synthesis of glucose in liver are amino acids, which are absorbed through the intestinal walls (Overton et al., 1999). This depends partly on the diet protein and energy quantities. Extracellular glucose is hormone regulated and the removal rate of glucose has been positively correlated to plasma insulin concentrations (Bassett et al., 1971). On the other hand, it is well known that propionic acid is insulinogenic (McAtee and Trenkle, 1971). Approximately, $50 \%$ of insulin secretion is through the parasympathetic nervous system through the activation of the pancreatic muscarinic receptors (Sano et al., 1993). The remaining secretion is regulated by glucose through pancreatic adrenergic B receptors (Sano et al., 1993).

Following the metabolic interactions briefly elaborated earlier, a higher proportion of concentrate (rich in energy and protein) would be translated into increased propionic acid concentrations. As a result, this will provide higher concentrations of glucose, insulin, thyroid hormones, and subsequent higher food conversion efficiency. This was verified in this study. Average daily weight gains and consumption parameters (OM, N, ME) were obtained with increased amounts of concentrate in the experimental diets. However, diets with at least $60 \%$ concentrate $(40 \%$ hay) appear necessary to detect significant differences among the study variables. No differences were found between diets $A$ and $B$ in the hormone and metabolite quantities, and parameters associated to consumption and growth. This study demonstrated the convenience of including higher amounts of concentrate in the diet of early-weaned calves for obtaining greater hormone and metabolite levels, and subsequent greater animal growth. 


\section{Conclusions}

Various diets differing in their concentrate/hay ratios were given to different-age calves. Diets were provided from 56 days prior to 60 days after weaning. Higher concentrate/hay ratios in the diet determined higher 1) hormones (insulin, $T_{3}, T_{4}$ ) and glucose in blood serum, nitrogen ammonia (post-ingesta) and propionic acid in rumen fluid; and 2) consumption (OM, N, ME) and growth parameters (ADWG) in calves after weaning them at 60 day-old. However, increasing dietary energy and protein in pre-weaned calves did not increase either 1) or 2). This indicates that beef producers should increase dietary energy and protein to calves after weaning them at 60 day-old, but not before.

\section{ACKNOWLEDGEMENTS}

We thank the Departamento de Agronomía, Universidad Nacional del Sur, Bahía Blanca, Argentina, that allowed the use of their animals and facilities to conduct this study. We also thank Silvia Canelo, Jorge Oyola and Arturo Ferro for their technical assistance.

\section{REFERENCES}

Acuti G, Todini L, Malfatti A, Antonini M, Barbato O, Trabalza-Marinucci M (2009). Effects of field bean (Vicia faba L. var. minor) dietary supplementation on plasma thyroid hormones, insulin, insulin-like growth factor-1 concentrations and mohair characteristics in growing Angora goat kids. J. Anim. Phys. Anim. Nutr., 93: 456-466.

Akayezu JM, Linn JG, Otterby DE, Hansen WP (1994). Evaluation of calf starters containing different amounts of crude protein for growth of Holstein calves. J. Dairy Sci., 77: 1882-1889.

AOAC (1990). Official methods of analysis. Association of the Official Analytical Chemists. $15^{\text {th }}$ edition. Washington, DC. 70 pp.

Bartlett KS, McKeith FK, VandeHaar MJ, Dahl GE, Drackley JK (2006). Growth and body composition of dairy calves fed milk replacers containing different amounts of protein at two feeding rates. J. Anim Sci., 84, 1454-1467.

Bartley EE (1973). Effects of a self-fed pelleted mixture of hay and calf starter on the performance of young dairy calves. J. Dairy Sci., 56 : 817-820.

Bassett JM, Weston RH, Hogan JP (1971). Dietary regulation of plasma insulin and growth hormone concentrations in sheep. Austr. J. Biol. Sci., 24: 321-330.

Bellver SP, Beermann AW, Van Tassell CP, Hogue DE, Mclaughlin CL (1995). Effects of exogenous somatotropin on whole-body glycemic response to insulin in young pre-ruminant and ruminant lambs. Domest. Anim. Endocrinol., 12: 143-156.

Berra G, Mate A, Catalini DG (1991). Calostro: Rol en la crianza de terneros. Detección de inmunidad. In: Círculo de médicos veterinarios (eds) Proceedings of the II Jornadas de Salud Animal. Paysandú, Uruguay. pp. 13-32.

Blome RM, Drackley JK, McKeith FK, Hutjens MF, McCoy GC (2003). Growth, nutrient utilization, and body composition of dairy calves fed milk replacers containing different amounts of protein. J. Anim. Sci. 81: 1641-1655.

Bragg A, Murphy MR, Davis CL (1986). Effect of source of carbohydrate and frequency of feeding on rumen parameters in dairy steers. J. Dairy Sci., 69: 392-402.

Breier BH, Bass JJ, Butler JH, Gluckman PD (1986). The somatotrophic axis in young steers: influence of nutritional status on pulsatile release of growth hormone and circulating concentrations of insulinlike growth factors. J. Endocrinol., 111: 209-215.

Chilliard Y, Bocquier F, Doreau M (1998). Digestive and metabolic adaptations of ruminants to undernutrition, and consequences on reproduction. Reprod. Nutr. Develop., 38: 131-152.

Cole NA, Purdy CW, Hallford DM (1988). Influence of fasting and postfast diet energy level on feed intake, feeding pattern and blood variables of lambs. J. Anim. Sci., 66: 798-805.

Danforth E, Burger AG (1989). The impact of nutrition on thyroid hormone physiology and action. Ann. Rev. Nutr., 9: 201-227.

Dixon WJ (ed) (1992). BMDP Statistical Software Manual. California: University of California Press. 678 pp.

Ekpe ED, Christopherson RJ (2000). Metabolic and endocrin responses to cold and feed restriction in ruminants. Can. J. Anim. Sci., 80: 87-95

Elías A (1986). Aplicación comercial de la melaza como alimento para rumiantes. In: Sansoucy R, Aarts G, Preston TR (eds) Proceedings of an FAO Expert Consultation, Santo Domingo, Dominican Republic; FAO Corporate Document Respository. Agriculture and Consumer Protection. Chapter 22, 8 pp.

Ellenberger MA, Johnson DE, Carstens GE, Hossner KL, Holland MD, Nett TM, Nockels CF (1989). Endocrine and metabolic changes during altered growth rates in beef cattle. J. Anim. Sci., 67: 14461454.

Fernández OA (2003). Los pastizales naturales del Caldenal. Anim. Acad. Nac. Agron. Vet., 57: 68-92.

Fernández OA, Busso CA (1999). Arid and semiarid rangelands: Two thirds of Argentina. In: Arnalds Ó, Archer S (eds) Proceedings of International Workshop of Rangeland Desertification Agricultural Research Institute. Reykjavic, Iceland. Rala Report № 200. pp. 41 60.

Fernández OA, Gil ME, Distel RA (2009). The challenge of rangeland degradation in a temperate semiarid region of Argentina: the Caldenal. Land Deg. Dev., 20: 431-440.

Friggens NC, Oldham JD, Dewhust RJ, Horgan G (1998). Proportions of volatile fatty acids in relation to the chemical composition of feeds based on grass silage. J. Dairy Sci., 81: 1331-1344.

Gerrits WJ, Decuypere E, Verstegen MWA, Karabinas V (1998). Effect of protein and protein-free energy intake on plasma concentrations of insulin-like growth factor-I and thyroid hormones in preruminant calves. J. Anim. Sci., 76: 1356-1363.

Gifford CA, Sosa AL, Knight RL, Loest CA, Hallford DM (2004). Body temperature and hormonal responses of sheep undergoing rumen cannulation. Proceedings, Western Section, Am. Soc. Anim. Sci., 55: 315-317.

Giorgetti HD, Busso CA, Montenegro OA, Rodríguez HD, Kugler NM (2006). Management techniques to improve cattle raising in central, semiarid rangelands of Argentina. Rangelands, 28: 32-36

Hammond AC, Huntington GB, Bitman J (1984). Effect of nitrogen intake on and rhythmicity of circulating thyroid hormones in steers. Domest. Anim. Endocrinol., 1: 29-42.

Khan MA, Lee HJ, Lee WS, Kim HS, Kim SB, Ki KS, Ha JK, Lee HG, Choi YJ (2007). Pre- and post-weaning performance of Holstein female calves fed milk through step-down and conventional methods. J. Dairy Sci., 90: 876-885.

Kincaid RL (1980). Alternate methods of feeding alfalfa to calves. J. Dairy Sci., 63: 91-94.

Kugler N, Giorgetti HD, Rodríguez HD, Cecchi G, Montenegro OA (2002). Destete convencional y destete precoz en el norte de la Patagonia. Información Técnica Nro. 21. Año 1. Nro. 3. 32 pp.

Kugler N, Giorgetti HD, Rodríguez GD, Cechi G, Montenegro OA Busso CA (2008). Cow performance in conventional and early weaning herds in north Patagonia, Argentina. Rangelands, 30: 12-16

Larson LL, Owen FG, Albright JL, Applemen RD, Lamb RC, Muller LD (1977). Guidelines toward more uniformity in measuring and reporting calf experimental data. J. Dairy Sci., 60: 989-991.

Lee HJ, Khan MA, Lee WS, Kim HS, Ki KS, Kang SJ, Hur TY, Khan MS, Choi YJ (2008). Growth, blood metabolites, and health of Holstein calves fed milk replacer containing different amounts of energy and protein. Asian-Aust. J. Anim. Sci., 21: 198-203.

Liebich HG, Dirksen G, Arbel A, Doris S, Mayer E (1987). Fed dependent changes of the ruminal mucosa of high producing dairy cows during the dry period and first eight weeks post partum. J. Vet. 
Med.Series A, 34: 661-672.

Lohakare JD, Pattanaik AK, Khan SA (2006). Effect of dietary protein levels on the performance, nutrient balances, metabolic profile and thyroid hormones of crossbred calves. Asian-Aust. J. Anim. Sci., 19: 1588-1596.

Matsunaga N, Arakawa NT, Goka T, Nam KT, Ohneda A, Sasaki Y, Katoh K (1999). Effects of ruminal infusion of volatile fatty acids on plasma concentration of growth hormone and insulin in sheep. Domest. Anim. Endocrinol., 17: 17-27.

Mc Atee JW, Trenkle A (1971). Metabolic regulation of plasma insulin levels in cattle. J. Anim. Sci., 33: 438-442.

Mc Donald P, Edwards RA, Greenhalgh JFD, Morgan CA (1995). Digestión. In: Nutricion Animal. Ed. Acribia, Zaragoza, Spain. pp. 157-164.

Mears GJ, Kozub GC (1994). Effect of selection for feedlot gain, breed and age on growth hormone and growth hormone kinetics in bull calves. Can. J. Anim. Sci., 75: 63-69.

Mears GJ, Schaalje GB (1993). Growth and growth hormone kinetics in Holstein steer calves. Can. J. Anim. Sci., 73: 277-285.

Menke KH, Steingass $H$ (1988). Estimation of the energetic feed value obtained from chemical analysis and in vitro gas production using rumen fluid. An. Res. Develop., 28: 7-55.

Murdock FR, Wallenius RW (1980). Fiber sources for complete calf starter rations. J. Dairy Sci., 63: 1869-1873.

Overton TR, Drackley JK, Ottemann-Abbamonte CJ, Breaulieu D, Emmert LS, Douglas GN, Clark JH (1999). Adaptations of ruminant glucose metabolism to increased glucose demand imposed experimentally or during the transition period of dairy cows. Illini Dairy Net. The online resource for the Dairy Industry. Doi: http://www.livestocktrail.uiuc.edu/dairynet/paperDisplay.cfm?contentl $\mathrm{D}=308$.

Pordomingo A (2002). Early weaning and length of supplementation effects on beef calves. J. Range Manage., 55: 327-335.

Quaia M, Zancai P, Cariati R, Rizzo S, Boiocchi M, Dolcetti R (2000). Glucocorticoids promote the proliferation and antagonize the retinoico acid-mediated growth supresión of Epstein-Barr virus-immortalized B lymphocytes. Blood, 96: 711-718.

Sano H, Hattori N, Todome Y, Tsuruoka J, Takahashi H, Terashima $Y$ (1993). Plasma insulin and glucagon responses to intravenous infusion of propionate and their autonomic control in sheep. J. Anim. Sci., 71: 3414-3422.

Santra A, Pathak NN (2000). Effect of dietary concentrate level on body immune response in calves fed a wheat straw-based diet. J. South Afr. Vet. Assoc., 71: 244-245.

Schaefer DM, Davis CL, Bryant MP (1980). Ammonia saturation constants for predominant species of rumen bacteria. J. Dairy Sci., 63: 1248-1263.

Steel RGD, Torrie JH (1980). Principles and procedures of statistics; a biometrical approach. Ed. McGraw-Hill, NY, USA. 481 pp.

Swenson MJ (1981). La sangre: propiedades fisiológicas y constituyentes celulares y químicos. In: Dukes $\mathrm{HH}$, Swenson MJ (eds) Fisiología de los animales domésticos. Funciones vegetativas. (Tomo I). Ed. Aguilar, México. pp. 27-77.

Todini L, Malfatti A, Valbonesi A, Trabalza-Marinucci M, Debenetti A (2007a). Plasma total $T_{3}$ and $T_{4}$ concentrations in goats at different physiological stages, as affected by the energy intake. Small Rum. Res., 68: 285-290.

Todini L, Trabalza-Marinucci M, Malfatti A, Barbato O, Stradaioli G, Cavallucci C, Debenedetti A (2007b). Pre- and post-feeding plasma gastrin-17 and insulin concentrations and feed intake in female goats during different physiological stages. Small Rum. Res., 71: 38-47.

Trenkle A (1989). Influence of feeding on growth hormone secretion and response to growth hormone releasing factor in sheep. J. Nutr., 119: 61-65.

Weatherburn MW (1967). Phenol-hypochlorite reaction for determination of ammonia. Anal. Chem., 39: 971-974.

Wholt JE, Allyn ME, Zajac PK, Katz LS (1994). Cortisol increases in plasma of Holstein heifers calves from handling and method of electrical dehorning. J. Dairy Sci., 77: 3725-3729.

Williams JE, Miller SJ. Mollet TA, Grebing SE, Bowman DK, Ellersieck MR (1987). Influence of frame size and zeranol on growth, compositional growth and plasma hormone characteristics. J. Anim. Sci., 65: 113-123.

Zhang S, Blache D, Blackberry MA, Graeme BM (2005). Dynamics of the responses in secretion of luteinising hormone, leptin and insulin following an acute increase in nutrition in mature male sheep. Reprod. Fert. Develop., 16: 823-829.

Zitnan R, Voigt J, Schonhusen U, Wegner J, Kokardová M, Hagemeister H, Levkut M, Kuhla S, Sommer A (1998). Influence of dietary concentrate to forage ratio on the development of rumen mucosa in calves. Arch. Anim. Nutr., 51: 279-291. 